\title{
Poverty and Malnutrition: Trends and Implications in Nigeria.
}

\author{
Elochukwu C.U \\ Department of Food Technology, Federal Polytechnic Oko, P.M.B. 021, \\ Anambra State, Nigeria.
}

\begin{abstract}
Poverty is a state of want where human beings are unable to meet their basic needs of household such as social amenities, nutrition and economic infrastructural development needed for survival. Poverty where ever it may exist, rural or urban have serious negative impact on the society. In Nigeria, poverty has a direct relationship with the nutrition and lifestyle of the people. Research study has identified that in Nigeria, $60 \%$ live below the so called poverty line, which is meant to be about \$1-\$2 a day per person. Healthy nutrition and lifestyle which is manifested when people are able to meet their basic needs of household such as social amenities, economic infrastructural development and access to adequate nutrient-rich food needed for survival are lacking in Nigeria. This review paper identified the concept of healthy nutrition. It further focused on the factors that cause poverty and malnutrition and the effects of poverty and hunger on an individual and the economy. The paper then recommends certain methods that can be adopted that to fight poverty and malnutrition in Nigeria. Therefore, any nation that strives for greater height in her development, must tackle the issue of poverty and malnutrition with all seriousness it deserves.
\end{abstract}

Keywords: Poverty, Nutrition, Hunger, Nigeria, Healthy, Malnutrition.

\section{INTRODUCTION}

Poverty is an undesirable state of affair. It is defined in absolute term as a situation where a population or section of population is able to meet only its bare subsistence essential of food, clothing and shelter in order to maintain a minimum standard of living. Poverty according to Ajegi (2002) is a state of want where human beings are unable to meet their basic needs of household such as social amenities and economic infrastructural development needed for survival. Poverty is also the state of deprivation of basic necessities of life which are the germane of meaningful existence. It is a situation where individuals and groups are not able to adequately cater for their basic needs of food, shelter and clothing to meet its social and economic obligations. Poverty may be absolute, relative, chronic, transient, mass or localized. In whatever form it may take, it inflicts both real and psychological pains on the people.

Poverty where ever it may exist, rural or urban have serious and negative impact on the society. Deviant behaviour experienced in our society today such as armed robber, prostitution, embezzlement, divorce, drug addiction and other forms of immorality are attributes of poverty (Anyanwu, 1993). The poor are those who lack adequate level of education and cannot satisfy their basic health needs (Sule, 2006). According to World Bank (2003), the poor are often regarded as illiterates, in poor health with short life span. It is a situation of extreme deprivation in living standard resulting from poverty and hunger.

Nutrition entails that the nutrients (carbohydrates, proteins, fats, minerals, salts, vitamins, water and fibre) must be in the diet in the proper quantity and proportion to one another to ensure maintenance of good health. These nutrients make up the food. Food is generally accepted as man's most important need. It is synonymous with livelihood. It is consumed by everyone alive and can only be optimized by the consumption of certain quantities and qualities at certain rates. Food is an important weapon in international diplomacy. The importance of food can be seen from two points. According to (Bamiseye, 1987), food is life hence food is an instrument of national power and food is used to achieve political ends because if people are well fed, they would be able and ready to contribute effectively to the implementation of government policies because a hungry nation is a weak one while a region subjected to famine and starvation is an insecure one. Ensuring that people have access to adequate nutrient-rich food and safe water is essential for protecting the safety, health and well-being 
of our teeming populations. According to (FAO ,2008), approximately one billion people worldwide are undernourished, many more suffer from micronutrients deficiencies and the absolute numbers tend to increase further, especially in sub Saharan Africa. Among the poor, the prevalent form of malnutrition is the deficiency type. Malnutrition results from nutrient deficiency of one nutrient to general deficiency of many nutrients, which is protein-energy malnutrition and even starvation. It is estimated that up to $30 \%$ of the world population have daily food intake that is below the minimum level necessary to sustain an accepted level of good health. Since the developing countries are poor and constitute more than half the world population, this form of malnutrition is prevalent (Okaka et al., 2006).

\section{HEALTHY NUTRITION}

Food is necessary for health, growth and normal function of living organisms. It is the material that enables man to grow and reproduce himself. Essentially food is a mixture of chemicals which could be separated into different components having different functions in the body. Nutrition involves the selection, ingestion and digestion of food on one hand, the absorption and utilization of the nutrients they contain on the other hand, and the elimination of waste for the wellbeing of man [Okaka et al., 2006]. The world health organization defines Nutrition as the intake of food, considered in relation to the body's dietary needs. They further stated that Good nutrition is an adequate, well balanced diet combined with regular physical activity which is a cornerstone of good health. Poor nutrition can lead to reduced immunity, increased susceptibility to disease, impaired physical and mental development, and reduced productivity. The idea that all people are entitled to have the physical needs of their bodies satisfied is at the heart of the human rights movement. This includes the right to survive and to live free of reasonably preventable suffering. The Declaration of Human Rights (UDHR) articulates this right to adequate health in Article 25:

"Everyone has the right to a standard of living adequate for the health and well-being of himself and of his family, including food, clothing, housing and medical care..." Hunger is an offspring of malnutrition.

\section{POVERTY AND Hunger IN Nigeria SOCIETY}

Hunger can be described as "a condition resulting from chronic under-consumption of food and/or nutritious food products". Essentially, in Nigeria, hunger results due to poverty. However, the poor are those who are unable to obtain healthy living conditions. Poverty and hunger in Nigeria society are caused by:

- Limited Productive Resources: Many Nigerians have limited or little productive resources on which to depend upon (Gbosi 2001). Most of them are unable to have adequate food on their dining tables. They lack farm implements as well as inputs such as seeds, fertilizer, and finance which are the germane of proper agricultural production. Most of them end up dying young because of different disease attack resulting from hunger. On the other hand, the non-farming segments of the poor population find it difficult to obtain soft loan to argument the financial base for their businesses (Idoko, 2015).

- Lack of Skill for Gainful Employment: The poor in the society are often the chronic illiterates who have never entered the foreword of education or acquired any skill meant for any gainful employment. Most of them especially in the rural areas depend on subsistence farming for livelihood. In urban areas, they live from hand to mouth by exposing their children into hawking, prostitution and other social vices (Ajegi, 2002).

- Differences in Environment: Environmental factors usually affect people differently. For instance, those who are born and brought up in poor families living in slums, getting bad food, having poor health and bad educational facilities are often bound to be poor when they grow up because of their environment (Ajiola, 2010). This is because the vicious cycle of poverty in them begins from birth and continues throughout their life time.

- Bad Governance: Bad governance, which has manifested through corruption, has been responsible for the poor economic performance of this country. According Dr(Mrs). Oby Ezekwesili in Daily Trust Newspaper of April 17, 2013, bad governance and corruption has made Nigeria unable to translate the huge natural resources at her disposal to improving her citizens' living standard. She pointed out that 69 percent of over 100 million Nigerians were living within the poverty bracket. 
- Misplacement of Priority: In Nigeria, most programmes and policies fail to address the felt needs of the people since in most cases; the choice and sitting of projects meant to eradicate poverty are done using political consideration, rather than the needs of the poor. For instance, the micro finance banks, the cooperative societies, the agric development banks and host of others established to encourage the poor in agricultural sector are mostly sited in urban and semi-urban centers instead of rural area of the country. This according to National Bureau of Statistics (2005) is a misplacement of priority since most people who benefits from the project in the areas they are sited may not be the real benefactors of the project

\section{EFFECTS OF POVERTY AND HUNGER ON INDIVIDUALS AND ECONOMY}

Poverty affects individuals and nations' economy negatively. This is because, poverty can thwart a nation's economic planning and lead to bad economic and social policies which can render the majority of the people neglected, dejected and hopeless Balogum (1999). The effects of poverty and hunger on individuals and economy include the followings:

- Distortion on Individuals and Economy as a Whole: Since extreme poverty and hunger result to low nutritional values, it distorts the growth pattern of individuals and groups in the society. Food as an essential ingredient for body growth according to Sule (2006) is required regularly in homes and in a nation at large. Any individuals or groups or nations that lack such essential items are likely to be exposed to diseases attack and other vices that can lead to death. On the other hand, a nation that is exposed to hunger and result into importation of food from foreign countries to augment its country's food intake may be exposed to further poor and unfavourable balance of payment (Balogum 1999),

- Deviant Behaviour: When people are poor, they look for means of livelihood. This means may result to deviant behaviour such as violence, corruption, prostitution, armed robbery, stealing, hawking and host of others.

- Lack of Peaceful Co-Existence: The saying goes that "a hungry man is an angry man". Extreme poverty posses' serious threat to peaceful co-existence between individuals and groups in the society. This means that if one is extremely poor, his/her co-existence with other people becomes very slim. Usually, the poor feels dejected, humiliated and rejected in the society.

- Limited Capacities: Poverty result to limited chance of capabilities such as meeting ones social and economic obligations, assets and social esteem. No individuals or groups can surely be flourished and happy when he or she is poor and miserable. Poverty according to Obadan (1997) has tremendous establishing potentialities because of its constraints on economic and social livings of the society.

\section{Methods that Can be Adopted in Fighting Poverty and Hunger in Nigeria}

There have been many methods and strategies that have been adopted to fight these two enemies of progress namely poverty and hunger. These policies and programmes could not work because of political instability and weak governance. However, to achieve the desired objectives of fighting poverty and hunger in Nigeria, the following strategies may be useful.

\section{Education of the Poor through Formal and Informal Channels}

The education of the poor through formal and informal channels may raise their level of illiteracy and help them understand their rights and civic responsibility as full citizens. This may eventually, resuscitate them into full awareness of the economy they belong and improve their production knowledge which in turn will bring them out of poverty and hunger.

\section{Provision of Training Opportunity through Skill Acquisition}

Training opportunities through skill acquisition established in different communities in the country may enhance the productivity of the people under extreme poverty encouraged to participate. This according Wodon (1997) will improve their income and hence poverty and hunger eradication. This practice has been introduced throughout the various channels or outlets. There is the need for adequate funding to ensure that this strategy is not distorted.

\section{Access to Land, Credit Facilities and Other Productive Resources}

Guaranteeing the access of the extreme poor to land, credit facilities and other productive resources may encourage them to improve in their potentialities to food production and income. This is because 
since access to land and credit are the major obstacles to the improvement of the welfare of the poor, its accessibility to whosoever is poor according to Ajegi (2002) will help in eradicating poverty and hunger in the society.

\section{Encourage Poor to Make Better Use of their Talents \& Local Productive Resources}

Most people in poverty are talented in one productive resources or the other but they are not encouraged to make better use of such talent. If they are encouraged, it will eventually improve their welfare and standard of living and poverty may be a thing of the past.

\section{Co-Ordination of all Existing Programmes and Institutions Involved in Poverty Eradication Efforts}

To achieve the objectives of poverty and hunger eradication, all existing programmes and institutions of poverty and hunger eradication efforts have to be coordinated and supervised to yield efficient result. This approach according to Sule (2006) will resuscitate individual and groups from the chronic devices of poverty enthronement

\section{SUGGESTIONS FOR IMPROVEMENT}

* The government should operate a welfare system in every nooks and corners of the country to cater for the poor, the aged and unemployed in the society.

* The government should make sure that policies or programmes meant to fight poverty and hunger in our society are not politicized.

* There is the need to educate the people on the right attitude towards government policies and programmes

* The government should establish poverty eradication agencies in different villages in the country to help in identifying the extreme poor and aid them though food aids to improve their nutritional values.

* Skill acquisition centers should be established in every nooks and corners of the grass root levels to exploit the talents and potentialities of extreme poor.

* Government should also give out interest- free loans to enable those who have acquired these skills to start their own manufacturing outfit

\section{CONCLUSION}

Poverty and Malnutrition are two brothers that thwart and disrupt the development process of a nation. They not only lead to physical deprivation of essential items for better condition of living, but have a serious psychological implication of the deprived. A poor nation is as a result of the aggregate poverty of its individual citizens. Therefore, any nation that strives for greater height in her development, must tackle the issue of poverty and malnutrition with all seriousness it deserves.

\section{REFERENCES}

[1] Ajegi, S.O. (2002). "The Affluence of Poverty: A Critical Evaluation of Nigeria's Poverty Reduction Program". Journal of Economic and Social Research (1) 1. Pp 60-63.

[2] Ajibola, A. (2010). "Ajibola Panel blames Jos crises on hunger "Nigeria compass, March 20th

[3] Anyanwu, J.C. (1993). Poverty in Nigeria: Concepts and Measurement, Poverty Alleviation in Nigeria. NES Annual Conference 1997.

[4] Balogun, E.D. (1999). "An Analyzing Poverty Concepts and Methods" Bullon (23) 4 Lagos CBN.

[5] Bamiseye, D.A. (1987), "Food Crisis and its Implication in Political Transformation of Nigeria since Independence" In Stephen, O. Olugbemi (Ed.), Alternative Political Futures for Nigeria, A publication of the Nigerian Political Publication, Lagos Nigeria.

[6] Edozie, V. (2014). Nigeria: Poor Governance, Stagnant Structure Cause Poverty - Ezekwesili Retrieved from http://www.dailytrust.com.ng/

[7] FAO, (2008). The State of Food Insecurity in the World, Food and Agriculture Organization, Rome 
[8] Gbosi, A.N. (2001). Contemporary Micro Economics Problems and Stabilization Policies, Port Harcourt: Antoric Ventures Nigeria.

[9] Idoko C. U. , Ibrahim, Y. and Agenyi,E. (2015). Fighting Poverty and Hunger in Nigeria For Sustainable Economic Development. International Journal of Economics, Commerce and Management United Kingdom Vol. III, Issue 3.

[10] National Bureau of Statistics, (2005). Poverty Profile for Nigeria, Federal Republic of Nigeria. pp. 37.

[11] Obadan, M. (1997), Analytical Framework for Poverty Reduction Issues of Economics Growth verses other Strategies. Nigeria Economic Society. Poverty Alleviation in Nigeria 1997 Annual Conference. pp 1-18.

[12] Okaka, JC, Akobundu ENT, and Okaka ANC (2006). Food and Human Nutrition: An Integrated Approach, OJC Academic Publishers, Enugu.

[13] Sule, J.Y. (2006). "Rural Development in Perspective. Lagos: Diolus Communications.

[14] Wodon, Q. (1997). Food Energy intake and Cost of Basic Needs: Measuring Poverty in Bangladesh Journal of Development Studies (34) pp. 66-101.

[15] World Bank, (2003). Development Indicators, Washington D.C. World Paper. pp 74-75. 